\title{
Production of five Merino type lines in a terminal crossbreeding system with Dormer or Suffolk sires
}

\author{
S.W.P. Cloete ${ }^{1,2 \#}$, J.J.E. Cloete ${ }^{1,2}$, A. Durand ${ }^{3}$ and L.C. Hoffman ${ }^{1}$ \\ ${ }^{1}$ Department of Animal Sciences, University of Stellenbosch, Private Bag X1, Matieland 7602, South Africa \\ ${ }^{2}$ Elsenburg Agricultural Centre, Private Bag X1, Elsenburg 7607, South Africa \\ ${ }^{3}$ Langgewens Experimental farm, Private Bag X2, Moorreesburg 7310, South Africa
}

\begin{abstract}
This study details the production performance of ewes and lambs that originated from a terminal crossbreeding experiment that involved five Merino type dam lines and two terminal crossbreeding sire lines from 1999 to 2002. Ewe lines were SA Mutton Merino (SAMM), SAMM rams crossed to Merino ewes (SAMM cross), Dohne Merino, as well as specialist Merino lines selected for clean fleece weight (FW+) and for an increased reproduction rate (Rep+). Dormer and Suffolk rams were used as sire breeds on these ewes. Data include 777 birth and 605 weaning records of lambs and 562 production year records of ewes. At birth the progeny of SAMM ewes were heavier than those of the other ewe lines, while FW+ ewes produced smaller lambs at birth than SAMM cross and Rep+ ewes. Lamb survival was not significantly affected by ewe line or sire breed. The progeny of the dual-purpose ewe lines (SAMM, SAMM cross and Dohne Merino) were heavier than those of Merino ewes (FW+ and Rep + ) at weaning. No sire breed difference was found for birth or weaning weight. The joining weights of dual-purpose ewe lines were higher than those of Merinos. Although considerable variation was found between ewe lines in terms of lamb output (number or weight of lamb weaned per ewe joined), the only significant difference was for weight of lamb weaned between SAMM cross and FW+ Merino ewes. Means for weight of lamb weaned per joining (in $\mathrm{kg}$ ) were 37.3 for SAMM ewes, 39.6 for SAMM cross ewes, 35.5 for Dohne Merino ewes, 28.9 for FW+ ewes and 34.6 for Rep + ewes. No differences in ewe reproduction were found between ewes joined to Dormer or Suffolk rams. The clean wool production of SAMM ewes amounted to $46 \%$ of that recorded in FW+ ewes. Corresponding percentages were $68 \%$ for SAMM cross ewes, $74 \%$ for Dohne Merino ewes and $90 \%$ for Rep+ ewes. The wool of SAMM ewes was slightly coarser in diameter than those of SAMM cross and FW+ ewes, which in turn was coarser than those of Rep+ and Dohne Merino ewes. The economic viability of crossbreeding programs involving the respective ewe lines would depend on the ratio between the prices of wool and lamb. No conclusive advantage could be demonstrated in favour of any of the sire breeds.
\end{abstract}

Keywords: Fibre diameter, lamb growth, lamb output, reproduction, South African sheep breeds, wool yield

${ }^{\sharp}$ Corresponding author. E-mail: schalkc@elsenburg.com

\section{Introduction}

Fluctuations in the ratio between wool and meat prices have resulted in the emphasis on the two products changing markedly over the past decade. This resulted in distinct changes in the South African Merino industry involving the adaptation of the breeding strategy for Merino sheep to enable an improved meat production capability (Olivier, 1999). Genetic change resulting from within-flock selection is comparatively slow, while it also takes time to filter through the structures of a breed. Commercial producers often seek other ways to exploit short-term benefits resulting from an increase in the price of meat without compromising the wool-producing capacity of their ewe flocks (Erasmus, 1965). Crossbreeding of Merino type ewes with mutton type rams in a terminal crossbreeding system is often seen as an option to achieve this goal (Kleeman et al., 1983). In this way it is possible for commercial producers to spread risk over the meat and wool commodities, while it is also possible to exploit the advantage of sexual dimorphism between dam and sire lines (Roux, 1992). In the past, this practice has often been implemented injudiciously, resulting in wool contamination and the loss of genetic material needed for pure breeding (Erasmus, 1965).

The purpose of this study was to evaluate a range of Merino-type bloodlines as dam lines in a terminal crossbreeding system. Dam lines were SA Mutton Merino (SAMM), SAMM rams crossed to commercial Merino ewes (SAMM cross), Dohne Merino, as well as a specialist Merino line selected for clean fleece weight and a second line selected for an increased reproduction rate. The SAMM and Dohne Merino breeds 
are regarded as the most important dual-purpose genotypes available to the local industry. Both breeds produce white, apparel wool, free from undesirable fibres. SAMM rams are also used on Merino ewes in the Western Cape for the breeding of first-cross ewes for the commercial production of lambs and wool. This cross was recommended for a dam line in slaughter lamb production systems (Kotze, 1950). Anecdotal reports claim that this cross is highly successful in enhancing the mutton production capacity of ewe flocks (A.J. Fourie, Pers. Comm. Bredasdorp-Napier Co-operation, Swellendam Road, Bredasdorp 7280, South Africa, 1999). Advantages in lamb output that could be attributed to heterosis were found even when Australian Merino bloodlines were crossed (Mortimer \& Atkins, 1997). The same reasoning would apply in the case of SAMM cross ewes. Data of the relative performance of such ewes in comparison to the parental breeds (SAMM and Merino) and the Dohne Merino breed (a synthetic derived from a cross between the SAMM and Merino breeds in the 1950s - Kotze, 1951) are scarce in the literature (Erasmus et al., 1983; Cloete \& Durand, 2000). All the genotypes that were mentioned above may play an important role in terminal crossbreeding systems, without seriously compromising wool quality.

Dormer and Suffolk rams were used as sire breeds on these ewes. The Dormer breed was developed for the purpose of providing a terminal crossbreeding sire breed for use on Merino ewes in the Western Cape (De Villiers \& Cloete, 1984). Suffolk rams are commonly used for this purpose (Wang et al., 1989: Nawaz et al., 1992).

Against this background, the relative performance of the respective dam lines in a commercial, terminal crossbreeding system was studied, using Dormer and Suffolk rams as sires.

\section{Material and Methods}

The experiment was carried out on the Langgewens experimental farm in the Swartland area of the Western Cape. The site is situated at $33^{\circ} 17^{\prime} \mathrm{S}$ and $18^{\circ} 42^{\prime} \mathrm{E}$. The climate is Mediterranean, $78 \%$ of the total long-term annual precipitation of $395 \mathrm{~mm}$ being recorded during winter (April to September). The experimental site is characterised by dry, hot and windy summers. Merino type ewes, belonging to five distinct lines, represented the female breeding animals under assessment. These ewes were born during 1997 and 1998, and were not selected as replacements for breeding purposes in their flocks of origin. They were thus considered to be ideal for diversification into slaughter lamb production in a terminal crossbreeding program. Evaluation took place over a four-year period, from 1999 to 2002 . Approximately 20 ewes within birth year groups (i.e. 40 in total for each ewe genotype) represented each line. Dormer or Suffolk rams were used as terminal sire breeds on the ewe flock. Dormer rams were obtained from the Elsenburg stud (Van Wyk, 1992) while Suffolk rams were obtained from industry. The maternal lines were the following:

- SAMM ewes from the Elsenburg flock (Vosloo, 1967). The flock participated in the SA Mutton Merino breed analysis that was reported by Neser et al. (2000). From this analysis it was evident that the maternal breeding values for 100-day weaning weight in the Elsenburg flock were consistently above the breed average, while direct breeding values were comparable to breed means. This line could thus be considered as acceptable material for a dam line in a terminal crossbreeding enterprise.

- A cross between SAMM rams from the Elsenburg flock described above and commercial Merino ewes (SAMM cross line; Cloete \& Durand, 2000).

- Dohne Merino ewes from the Kromme Rhee Dohne Merino flock (Cloete et al., 1998b) for ewes born in 1997. This flock served as a nucleus flock for the Western Cape Dohne club. Since all the leading breeders in the area contributed breeding material, the flock could be considered as representative of the available breeding material. The flock was disbanded during 1997, owing to logistic problems, and the 1998-drop ewes could not be obtained from it. Twenty commercial two-tooth ewes were thus bought in from a nearby property to provide a 1998 ewe group.

- A specialist Merino line that has been selected since 1969 for clean fleece weight, with a check on fibre diameter on the male side (FW+; Cloete et al., 1998a). This line is being maintained on the Tygerhoek experimental farm near Riviersonderend in the Southern Cape.

- A specialist Merino line that was selected since 1986 for the ability to rear multiple lambs per joining (Rep+ line; Cloete \& Scholtz, 1998). This line was maintained on the Elsenburg experimental farm during the period that ewes were obtained from it. 
Cognisance is taken of the fact that the flocks where the ewes were bred and the location and management where they grew up differed for the two-tooth ewes introduced to the experimental flock, except for the SAMM cross ewes. The latter were born and bred at Langgewens. The SAMM, SAMM cross and FW+ maiden ewes were approximately 22 months old at first joining in February 1999 and 2000. The Rep+ ewes were approximately 18 months and the Dohne Merino ewes approximately 16 months old. Prior to the 1999 joining, SAMM, Dohne Merino and Rep+ Merino ewes were transported to Langgewens only approximately one month prior to joining. In preliminary analyses, it was evident that carry-over effects from the location where they grew up were still present in live weight at joining. Seeing that approximately four months wool growth were grown on the locality of origin of the respective ewe lines, marked influences were also observed on wool traits. Prior to the 2000 joining, the 1998-born ewes were introduced to Langgewens at least five months prior to joining. No evidence of carry-over effects from the location where they grew up was observed in either joining weight or wool traits. The wool clip shorn during 2001 and 2002 was entirely produced on the Langgewens locality.

All available ewes were joined to lamb during June-July of each year. Individual live weights at joining were recorded. Two rams of each sire breed were used in single sire groups during 1999, when only the ewes born in 1997 were available. Three rams of each breed were used during 2000 to 2001. During 2002, when only 1998-drop ewes were available, two rams were once again used per sire breed. During the latter three years, one ram of each breed was retained for breeding, to provide sire links across years. All lambs were weaned during October at approximately 100 days of age. Parentage, contemporary group, survival to weaning and weaning weight were recorded for all lambs. It was possible to construct complete reproduction data for all ewes from this information. During each year, all available ewes were shorn during May-June, within four weeks of the commencement of lambing. Individual greasy fleeces were weighed at this stage and midrib samples were taken for further analysis. Clean yield, staple strength and fibre diameter were measured on these samples. Clean yield measurements were then used to calculate clean fleece weight.

The experimental flock grazed small grain cereal stubble during joining. The flock was retained on stubble lands until green feed became available after autumn and early winter rains. Medic pastures were mostly utilised during winter. Oat fodder crops were occasionally available. Limited supplementation was provided to lambs born during 2001 when uncharacteristically poor early summer conditions were experienced. No further supplementation was provided at any stage, but a fairly general health program for the area was followed. The ewes were maintained in a single flock for the duration of the experiment, except during joining in single sire groups and during peak lambing. Ewes were spread across 2-3 paddocks at this stage to reduce the density of lambing ewes per paddock.

A total of 562 reproduction records of ewes that were joined, was available for analysis. Joining weight and fleece data of 1999 were not considered, as motivated earlier. Only 464 joining weight records were thus used, while 462 records were considered in the analysis of wool traits. A total number of 777 lambs was recorded at birth, and 605 at weaning.

Least squares procedures were used to assess the data statistically, to account for uneven subclasses. The ASREML statistical package (Gilmour et al., 1999) allows the estimation of a range of random effects in animal breeding, while also predicting estimates of appropriate least-squares means for selected fixed effects. Fixed effects that were considered in the analyses of lamb traits (birth weight, pre-weaning mortality and weaning weight) were birth year, sex, birth type, dam line and sire breed as well as relevant interactions. Binomially distributed lamb mortality data were linked to the normal distribution by the logit transformation (Gilmour et al., 1999). Since interactions were not significant in the vast majority of cases, only main effect means were tabulated. Information is supplied in the text in those cases where significant interactions were found. Age of dam was confounded with production years and was thus not considered. A linear regression on weaning age was fitted for weaning weight. Random sire within ram breed and maternal permanent environmental effects were also computed. Back pedigrees were not included for sires and dams, since all sires and dams were derived from different flocks. It was thus not attempted to fit maternal genetic effects. It would also be of limited application in a terminal crossbreeding system where all female progeny are slaughtered. Genetic and ewe permanent environmental parameters generally corresponded with literature estimates (see Duguma et al., 2002 for tabled literature estimates), and are thus not presented.

Production year, dam line and sire breed were typically fitted as fixed effects in the case of ewe reproduction and wool traits. Random animal effects stemming from repeated records on the same individuals were computed and used to derive repeatability estimates. It was not attempted to partition the animal effects into genetic and permanent environmental components, following the reasoning provided 
earlier. Repeatability estimates for reproduction and wool traits were not presented, since they accorded with literature estimates. Random service sire effects were also obtained in the case of lamb output, as reflected by number of lambs born, number of lambs weaned and total weight of lamb weaned. These effects only accounted for $2-3 \%$ of the overall phenotypic variance, and are not discussed in detail. It is conceded that the analysis of discrete data such as number of lambs born and weaned with parametric methods used in the present study is not optimal, as was outlined by Purvis \& Hillard (1997). The availability of suitable software, and the close approximation of outcomes from linear models to those derived from non-linear methods have resulted in recommendations that the former methods could be employed until alternative software packages become readily available (Jorhensen, 1994; Brien et al., 2002).

\section{Results and Discussion}

Birth weight was affected by a significant $(\mathrm{P}<0.05)$ interaction between ewe line and birth type. The single progeny of SAMM cross ewes were $13 \%$ heavier than multiples $(5.57 \pm 0.16 v s .4 .93 \pm 0.11 \mathrm{~kg}$ respectively). Corresponding differences for the other ewe lines were $20 \%$ for SAMM ewes $(6.04 \pm 0.15 v s$. $5.02 \pm 0.11 \mathrm{~kg}), 21 \%$ for FW+ Merino ewes $(5.37 \pm 0.15$ vs. $4.45 \pm 0.13 \mathrm{~kg}), 25 \%$ for Dohne Merino ewes $(5.75 \pm 0.15 v s .4 .60 \pm 0.13 \mathrm{~kg})$ and $30 \%$ for Rep+ Merino ewes $(5.91 \pm 0.14 v s .4 .54 \pm 0.12 \mathrm{~kg})$. Single lambs were heavier $(\mathrm{P}<0.05)$ at birth than multiples (Table 1). No birth weight difference was obtained between lambs sired by Dormer or Suffolk rams. No significant differences were obtained as far as lamb mortality was concerned, although ewe lambs tended $(\mathrm{P}=0.10)$ to have a lower mortality than ram lambs. There was also a tendency $(\mathrm{P}<0.10)$ towards differences in lamb mortality between birth years. Although the absolute variation in lamb mortality between ewe lines was sufficiently large to be economically important, the derived $\mathrm{F}$-value only indicated significance at $\mathrm{P}<0.25$. In general, the effects of sex and birth type on birth weight and lamb mortality were in correspondence with literature reports and will not be elucidated further. The only exception was with regard to lamb mortality. No difference was found between singles and multiples, while multiples are expected to sustain higher mortality levels. Yet a number of previous studies have shown that the survival of single and twin lambs was similar in relatively high performing flocks (Brand et al., 1985; Cloete, 1992; Holst et al., 1997; Cloete et al., 1999a).

Table 1 Least squares means ( \pm s.e.) for lamb birth weight, weaning weight at 100 days of age and survival prior to weaning as affected by birth year, sex, birth type, ewe line and sire breed

\begin{tabular}{|c|c|c|c|c|}
\hline \multirow[t]{2}{*}{ Fixed effect } & \multirow{2}{*}{$\begin{array}{c}\text { Birth weight } \\
\mathrm{kg}\end{array}$} & \multirow{2}{*}{$\begin{array}{l}\text { Weaning weight } \\
\mathrm{kg}\end{array}$} & \multicolumn{2}{|c|}{ Lamb mortality } \\
\hline & & & Logit scale & Normal scale \\
\hline Number of observations & 777 & 605 & 777 & \\
\hline Overall mean & $5.22 \pm 0.05$ & $34.3 \pm 0.3$ & $-1.316 \pm 0.132$ & 0.221 \\
\hline Birth year & $* *$ & $* *$ & 0.10 & \\
\hline 1999 & $4.92 \pm 0.09$ & $34.9 \pm 0.7$ & $-1.001 \pm 0.252$ & 0.269 \\
\hline 2000 & $5.75 \pm 0.07$ & $36.3 \pm 0.5$ & $-1.538 \pm 0.199$ & 0.179 \\
\hline 2001 & $5.14 \pm 0.07$ & $31.0 \pm 0.5$ & $-1.041 \pm 0.184$ & 0.261 \\
\hline 2002 & $5.07 \pm 0.09$ & $35.1 \pm 0.7$ & $-1.687 \pm 0.294$ & 0.156 \\
\hline Sex & $* *$ & $* *$ & 0.10 & \\
\hline Ram & $5.39 \pm 0.06$ & $35.7 \pm 0.4$ & $-1.160 \pm 0.156$ & 0.239 \\
\hline Ewe & $5.04 \pm 0.06$ & $32.9 \pm 0.4$ & $-1.473 \pm 0.167$ & 0.186 \\
\hline Birth type & $* *$ & $* *$ & ns & \\
\hline Single & $5.73 \pm 0.07$ & $36.8 \pm 0.4$ & $-1.268 \pm 0.186$ & 0.220 \\
\hline Multiple & $4.71 \pm 0.06$ & $31.7 \pm 0.3$ & $-1.365 \pm 0.147$ & 0.204 \\
\hline Dam line & $* *$ & $* *$ & ns & \\
\hline SAMM & $5.53 \pm 0.11$ & $36.3 \pm 0.5$ & $-1.012 \pm 0.226$ & 0.266 \\
\hline SAMM cross & $5.25 \pm 0.11$ & $34.8 \pm 0.6$ & $-1.141 \pm 0.232$ & 0.242 \\
\hline Dohne Merino & $5.18 \pm 0.11$ & $35.7 \pm 0.5$ & $-1.695 \pm 0.273$ & 0.155 \\
\hline $\mathrm{FW}+$ & $4.91 \pm 0.11$ & $32.3 \pm 0.5$ & $-1.187 \pm 0.246$ & 0.234 \\
\hline Rep+ & $5.22 \pm 0.11$ & $32.3 \pm 0.5$ & $-1.548 \pm 0.259$ & 0.175 \\
\hline Sire breed & ns & ns & ns & \\
\hline Dormer & $5.21 \pm 0.07$ & $34.6 \pm 0.5$ & $-1.353 \pm 0.158$ & 0.205 \\
\hline Suffolk & $5.23 \pm 0.07$ & $34.0 \pm 0.5$ & $-2.281 \pm 0.199$ & 0.218 \\
\hline Regression on age (d) & - & $0.290 \pm 0.016^{* *}$ & - & - \\
\hline
\end{tabular}

The South African Journal of Animal Science is available online at www.sasas.co.za/Sajas.html 
Lambs born in 2001 had lower $(\mathrm{P}<0.05)$ weaning weights than those born in the other years. Ram lambs and singles were heavier $(\mathrm{P}<0.05)$ than ewes and multiples at weaning. Crossbred lambs produced by dual-purpose ewes (SAMM, SAMM cross and Dohne Merino) were between 8 and 12\% heavier (P< 0.05 ) at weaning than those produced by Merinos (Table 1). No corresponding results were found in the literature with regard to the breeds used in terminal crossbreeding. It was, however, found that weaning weights of purebred SAMM and Dohne Merino lambs were between 17 and 35\% heavier than that of Merinos (see Table 4 for a summary of available literature). Keeping in mind that only the dam component was considered in the present study, these results are in adequate agreement with those obtained from the pure breeds regarding direction and magnitude.

The present results did not suggest a sire line difference (Table 1). In the only other local study that could be found where Dormer and Suffolk rams were compared as terminal crossbreeding sires, no differences were correspondingly reported for lamb growth, as reflected by lamb carcass weight when slaughtered at a fixed age (Erasmus et al., 1983). The latter study also reported no significant differences in lamb mortality between the progeny of the two breeds. When averaged across ewe lines, the overall lamb mortality of lambs sired by Dormer rams was $12.1 \%$, compared to $14.4 \%$ for Suffolk sires.

Ewe joining weight increased from 2000 to 2002, as the breeding ewes approached mature live weight. Ewes from the dual-purpose breeds (SAMM, SAMM cross and Dohne ewes) were between 10 and $13 \%$ heavier $(\mathrm{P}<0.05)$ than $\mathrm{FW}+$ Merino ewes and between 24 and $28 \%$ heavier than Rep+ Merino ewes. Yearling or mature live weights of dual-purpose ewes were between 17 and $33 \%$ heavier than those of Merinos in the literature (Table 4), which is in adequate agreement with the outcome of the present study.

Table 2 Least squares means ( \pm s.e.) for ewe reproduction, as affected by year, dam line and sire breed. All reproduction traits were expressed in relation to ewes joined

\begin{tabular}{lcccc}
\hline Effect & Ewe joining weight & $\begin{array}{c}\text { Number of lamb } \\
\text { born }\end{array}$ & $\begin{array}{c}\text { Number of lambs } \\
\text { weaned }\end{array}$ & $\begin{array}{c}\text { Weight of lamb } \\
\text { weaned } \\
\mathrm{kg}\end{array}$ \\
\hline Number of observations & $\mathrm{kg}$ & & & 562 \\
Overall mean & $57.4 \pm 0.5$ & $1.37 \pm 0.04$ & $1.07 \pm 0.04$ & $35.2 \pm 1.5$ \\
Year & $* *$ & $\mathrm{~ns}$ & $*$ & $* *$ \\
1999 & - & $1.22 \pm 0.08$ & $0.87 \pm 0.09$ & $28.7 \pm 3.1$ \\
2000 & $51.8 \pm 0.6$ & $1.39 \pm 0.06$ & $1.13 \pm 0.07$ & $37.6 \pm 2.3$ \\
2001 & $58.2 \pm 0.5$ & $1.42 \pm 0.06$ & $1.05 \pm 0.07$ & $31.8 \pm 2.3$ \\
2002 & $62.3 \pm 0.6$ & $1.45 \pm 0.08$ & $1.21 \pm 0.10$ & $42.7 \pm 3.1$ \\
Dam line & $* *$ & $* *$ & $\mathrm{~ns}$ & $*$ \\
SAMM & $60.3 \pm 1.0$ & $1.47 \pm 0.07$ & $1.07 \pm 0.08$ & $37.3 \pm 2.8$ \\
SAMM cross & $62.3 \pm 1.0$ & $1.59 \pm 0.08$ & $1.19 \pm 0.09$ & $39.6 \pm 2.8$ \\
Dohne & $60.9 \pm 1.0$ & $1.23 \pm 0.08$ & $1.01 \pm 0.09$ & $35.5 \pm 2.8$ \\
FW+ & $54.9 \pm 1.0$ & $1.21 \pm 0.08$ & $0.95 \pm 0.09$ & $28.9 \pm 2.8$ \\
Rep+ & $48.7 \pm 1.0$ & $1.34 \pm 0.08$ & $1.11 \pm 0.09$ & $34.6 \pm 2.8$ \\
Sire breed & $\mathrm{ns}$ & $\mathrm{ns}$ & $\mathrm{ns}$ & $\mathrm{ns}$ \\
Dormer & $57.8 \pm 0.6$ & $1.37 \pm 0.06$ & $1.09 \pm 0.06$ & $36.2 \pm 2.2$ \\
Suffolk & $57.0 \pm 0.7$ & $1.37 \pm 0.06$ & $1.05 \pm 0.06$ & $34.2 \pm 2.2$ \\
\hline
\end{tabular}

ns - Not significant $(\mathrm{P}>0.10)$

* - Significant $(\mathrm{P}<0.05)$

** - Significant $(\mathrm{P}<0.01)$

Ewes in the SAMM and SAMM cross lines produced more $(\mathrm{P}<0.05)$ lambs born per ewe joined than $\mathrm{FW}+$ Merino and Dohne ewes, with the Rep+ Merinos being intermediate (Table 2). Expressed relative to FW+ Merinos, the advantage amounted to $21 \%$ and $31 \%$ respectively in favour of SAMM and SAMM cross ewes. Number of lambs born per ewe joined was independent of year of lambing and the breed of the service sire. Differences between lambing years were significant $(\mathrm{P}<0.05)$ for number of lambs weaned per joining, which was unaffected $(\mathrm{P}>0.10)$ by dam line and breed of service sire. In the only other study where the respective ewe breeds were assessed under terminal crossbreeding conditions, SAMM ewes had a 25\% advantage over Merino ewes for number of lambs born per ewe joined (Erasmus et al., 1983 - Table 4). 
No marked advantage of SAMM ewes was correspondingly found for number of lambs weaned per ewe joined. The mean for lambs marked per ewe joined was 28\% higher in SAMM flocks than in Merino flocks (Table 4). All studies summarised from the literature reported only modest improvements in the reproduction of Dohne ewes compared to Merinos. Total weight of lamb weaned per joining differed $(\mathrm{P}<0.01)$ between lambing years, but was independent of the breed of the service sire (Table 2). Total weight of lamb weaned per joining was $37 \%$ higher $(\mathrm{P}<0.05)$ in SAMM cross ewes than in $\mathrm{FW}+$ Merino ewes. Differences in weight of lamb weaned of dual-purpose ewes ranged from 18 to $43 \%$ compared to Merinos in studies on purebred ewes (Table 4).

No differences were found between the two terminal sire breeds as far as the reproduction of their ewe mates was considered. In this respect, it could be stated that Erasmus et al. (1983) reported average figures of respectively 1.20 lambs born and 1.06 lambs weaned per ewe joined for ewes joined to Dormer rams, compared to respective figures of 1.20 and 1.03 for Suffolk rams. Similar observations were made in studies where other sire breeds were considered (Wang et al., 1989; Bunge et al., 1993; Carson et al., 1999).

The clean fleece weight produced by ewes generally decreased $(\mathrm{P}<0.05)$ from 2000 to 2002 (Table $3)$, while fibre diameter generally increased. Clean yield was higher $(\mathrm{P}<0.05)$ in 2001 than in 2000 and 2002 , but staple strength was adversely affected $(\mathrm{P}<0.05)$ during 2001 relative to 2000 and 2002. Clean fleece weight, clean yield and staple strength improved $(\mathrm{P}<0.05)$ from SAMM ewes to $\mathrm{FW}+$ ewes. The clean wool production of SAMM ewes amounted to $46 \%$ of that recorded in FW+ ewes. Corresponding percentages were $68 \%$ for SAMM cross ewes, $74 \%$ for Dohne Merino ewes and $90 \%$ for Rep+ ewes. Wool production of SAMM ewes amounted from 52 to $57 \%$ of that produced by Merinos (Table 4). The quantity of wool produced by Dohne and SAMM cross ewes amounted to between 64 and $83 \%$ of that expected from Merinos.

Expressed relatively to FW+ Merino ewes, clean yield amounted to $86 \%$ for SAMM ewes, $91 \%$ for SAMM cross ewes and $96 \%$ for Dohne Merino ewes, all differences being significant $(\mathrm{P}<0.05)$. The clean yield of SAMM wool amounted to between 87 and $88 \%$ of that yielded by Merino wool in the literature (Table 4). Corresponding percentages for Dohne Merino and SAMM cross wool ranged from 90 to $95 \%$ of the clean yield of Merino wool. The present results are in adequate agreement with these findings.

Table 3 Least squares means ( \pm s.e.) for wool traits, as affected by year and dam line. Means for sire breed were not computed, since no theoretical basis existed for such a difference

\begin{tabular}{lcccc}
\hline & Clean fleece weight & Clean yield & Staple strength & \multicolumn{2}{c}{ Fibre diameter } \\
Effect & $\mathrm{kg}$ & 462 & $\mathrm{~N} / \mathrm{ktex}$ & $\mu \mathrm{m}$ \\
\hline Number of observations & $3.55 \pm 0.05$ & $67.4 \pm 0.3$ & 362 & 462 \\
Overall mean & $* *$ & $* *$ & $6.1 \pm 0.6$ & $23.0 \pm 0.1$ \\
Year & $3.85 \pm 0.06$ & $66.9 \pm 0.4$ & $37.2 \pm 0.8$ & $22.7 \pm 0.1$ \\
2000 & $3.50 \pm 0.06$ & $68.5 \pm 0.4$ & $32.0 \pm 0.8$ & $23.0 \pm 0.1$ \\
2001 & $3.30 \pm 0.07$ & $66.8 \pm 0.5$ & $36.0 \pm 1.1$ & $23.4 \pm 0.1$ \\
2002 & $* *$ & $* *$ & $* *$ & $* *$ \\
Dam line & $2.16 \pm 0.11$ & $61.0 \pm 0.7$ & $28.6 \pm 1.3$ & $23.7 \pm 0.2$ \\
SAMM & $3.19 \pm 0.12$ & $64.9 \pm 0.8$ & $32.9 \pm 1.4$ & $23.3 \pm 0.2$ \\
SAMM cross & $3.48 \pm 0.12$ & $68.6 \pm 0.8$ & $37.2 \pm 1.3$ & $22.1 \pm 0.2$ \\
Dohne & $4.69 \pm 0.12$ & $71.3 \pm 0.8$ & $41.6 \pm 1.4$ & $23.3 \pm 0.2$ \\
FW+ & $4.23 \pm 0.12$ & $71.3 \pm 0.8$ & $35.7 \pm 1.4$ & $22.8 \pm 0.2$ \\
Rep+ & & & & \\
\hline
\end{tabular}

** - Significant $(\mathrm{P}<0.01)$

Staple strength increased $(\mathrm{P}<0.05)$ from SAMM ewes to $\mathrm{FW}+$ ewes (Table 3). Relative to a value of $100 \%$ for FW+ Merino ewes, average performance levels amounted to $69 \%$ for SAMM ewes, $79 \%$ for SAMM cross ewes, $89 \%$ for Dohne Merino ewes and $86 \%$ for Rep+ Merino ewes. No corresponding results were found in the literature. In general, staple strength was within or above the range of 25 to $30 \mathrm{~N} / \mathrm{ktex}$, which is considered as sound (Read, 1996; Scrivener \& Vizard, 1997).

The wool of SAMM ewes was approximately $2 \%$ coarser $(\mathrm{P}<0.05)$ than that of FW+ Merino ewes. The fibre diameter of Dohne Merino and Rep+ ewes amounted to respectively $95 \%$ and $98 \%$ of FW + ewes $(\mathrm{P}<0.05)$. It is of interest to note that the fibre diameter of SAMM was only slightly coarser than those of SAMM cross and FW+ Merinos, with Dohne Merino ewes having slightly lower $(\mathrm{P}<0.05)$ means for fibre 
diameter. The fibre diameter of SAMM sheep was found to be between 2 and $8 \%$ coarser than that of Merinos (Table 4). In the literature, fibre diameter of Dohne Merinos was comparable to that of Merinos where measured. The comparatively high fibre diameter of the FW+ line should also be seen from the context that this line was found to show a more pronounced increase in fibre diameter with age than the control line maintained alongside (Cloete et al., 1999b). Ewes with an excessive fibre diameter would also not be considered as replacements in the FW + and Rep + lines. They would, however, still be considered for terminal crossbreeding, provided that they were of sound constitution. The chances that such ewes ended up as crossbred dams in the present study are thus good. Given the relatively high repeatability of fibre diameter (Cloete et al., 1999b), this could also have contributed to the observed results.

Table 4 A summary of literature findings pertaining to the performance of the respective ewe lines evaluated during the study. Means were expressed relative to a value of 100 for Merinos, and provided in parentheses for the other lines

\begin{tabular}{|c|c|c|c|c|}
\hline \multirow[t]{2}{*}{ Trait and study } & \multicolumn{4}{|c|}{ Line } \\
\hline & SAMM & SAMM cross & Dohne Merino & Merino \\
\hline \multicolumn{5}{|l|}{ Lamb weaning weight (kg): } \\
\hline Basson et al. (1969) & - & - & $23.5(120)$ & 19.6 \\
\hline Cloete et al. (1999a) & $32.2(124)$ & - & $30.2(117)$ & 25.9 \\
\hline Brand \& Franck (2000) & $27.9(135)$ & - & - & 20.6 \\
\hline \multicolumn{5}{|l|}{ Lambs born per ewe joined: } \\
\hline Basson et al. (1969) & - & - & $1.21(103)$ & 1.18 \\
\hline Erasmus et al. (1983) & $1.10(125)$ & - & $0.99(113)$ & 0.88 \\
\hline \multicolumn{5}{|l|}{ Lambs weaned per ewe joined: } \\
\hline Basson et al. (1969) & - & - & $1.08(98)$ & 1.10 \\
\hline Erasmus et al. (1983) & $0.85(104)$ & - & $0.86(105)$ & 0.82 \\
\hline \multicolumn{5}{|l|}{ Lambs marked per ewe joined: } \\
\hline Fourie \& Cloete (1993) & $1.13(128)$ & - & $0.93(106)$ & 0.88 \\
\hline \multicolumn{5}{|l|}{ Weight of lamb weaned (kg): } \\
\hline Basson et al. (1969) - derived from means & - & - & $25.4(118)$ & 21.6 \\
\hline Cloete et al. (1999a) & $44.7(143)$ & - & $41.8(134)$ & 31.3 \\
\hline \multicolumn{5}{|l|}{ Yearling or adult live weight $(\mathrm{kg})$ : } \\
\hline Basson et al. (1969) & - & - & $60.0(124)$ & 48.2 \\
\hline Cloete et al. (1999a) & $57.4(133)$ & - & $50.7(117)$ & 43.3 \\
\hline Cloete \& Durand (2000) & - & $53.0(126)$ & - & 42.0 \\
\hline \multicolumn{5}{|l|}{ Greasy fleece weight $(\mathbf{k g})$ : } \\
\hline Basson et al. (1969) & - & - & $4.1(79)$ & 5.2 \\
\hline Brand et al. (1999) & $2.8(54)$ & - & - & 5.2 \\
\hline Brand \& Franck (2000) & $1.6(57)$ & - & - & 2.8 \\
\hline Cloete \& Durand (2000) & - & $3.9(83)$ & - & 4.7 \\
\hline \multicolumn{5}{|l|}{ Clean fleece weight $(\mathrm{kg})$ : } \\
\hline Basson et al. (1969) - derived from means & - & - & $2.1(70)$ & 3.0 \\
\hline Greeff (1990) & $2.9(52)$ & - & $3.6(64)$ & 5.6 \\
\hline Cloete et al. (1999a) & $1.5(54)$ & - & $2.0(71)$ & 2.8 \\
\hline Cloete \& Durand (2000) & - & $2.6(79)$ & - & 3.3 \\
\hline \multicolumn{5}{|l|}{ Clean yield $(\%)$ : } \\
\hline Basson et al. (1969) & - & - & $52.4(90)$ & 58.5 \\
\hline Brand et al. (1999) & $64.8(88)$ & - & - & 73.4 \\
\hline Cloete et al. (1999a) & $64.0(87)$ & - & $68.9(93)$ & 73.9 \\
\hline Cloete \& Durand (2000) & - & $66.8(95)$ & - & 70.5 \\
\hline \multicolumn{5}{|l|}{ Fibre diameter $(\mu \mathrm{m})$ : } \\
\hline Greeff (1990) & $23.3(102)$ & - & $23.6(103)$ & 22.8 \\
\hline Brand et al. (1999) & $23.1(105)$ & - & - & 22.0 \\
\hline Cloete et al. (1999a) & $23.7(108)$ & - & $21.8(99)$ & 21.9 \\
\hline Cloete \& Durand (2000) & - & $21.8(107)$ & - & 20.3 \\
\hline
\end{tabular}




\section{Conclusions}

It was evident that SAMM cross and Dohne ewes performed at least as well as purebred SAMM ewes with regard to lamb output in the terminal crossbreeding situation, while they had a clear advantage in terms of wool production. Advantages in wool weight and wool quality resulted in Dohne ewes being accordingly more efficient in economic terms than SAMM ewes (Schoeman, 1990). The same reasoning applies to Rep+ Merino ewes. It has to be conceded that the slower growth of progeny of the latter line may increase the risk involved in a crossbreeding program based on such ewes under conditions where a seasonal short supply of nutrients is expected. Part of the adaptability of a terminal crossbreeding system is the opportunity to maintain only the ewe breeding flock over a period of nutritional short supply, like the summer period in the Swartland. The slower growth by progeny of both Merino lines may make a system based on such ewes more risky. This element of risk will be compensated for by additional security in terms of a higher and more stable wool income from such dams during periods when the wool price is high.

No definite advantage for either of the ram lines could be demonstrated. Decision-making should thus be based on factors such as the availability of rams, and considerations like the probability of contamination with coloured fibres in the case of the Suffolk breed (Erasmus et al., 1983).

\section{Acknowledgement}

We gratefully acknowledge the support of the staff at the Langgewens experimental farm during the experiment, and the technical inputs of A.J. Scholtz and J.E. Fourie. The experiment was supported financially by the South African Red Meat Research and Development Trust. The South African Wool Industry supported the development of the Rep+ line financially. We are also grateful to the Western Cape Dohne Merino club, for the donation of the 1997 born progeny from the Kromme Rhee nucleus flock.

\section{References}

Basson, W.D., Van Niekerk, B.D.H., Mulder, A.M. \& Cloete, J.G., 1969. The productive and reproductive potential of three breeds mated at 8-monthly intervals under intensive feeding conditions. Proc. S. Afr. Soc. Anim. Prod. 8, 149-154.

Brand, A.A., Cloete S.W.P. \& De Villiers, T.T., 1985. Faktore wat lamvrektes by die Elsenburg Dormer-en SA Vleismerinokuddes beïnvloed. S. Afr. Tydskr. Veek. 15, 155-161.

Brand, T.S. \& Franck, F., 2000. Production responses of two genetic different types of Merino sheep to different nutritional levels. Small Rumin. Res. 37, 85-91.

Brand, T.S., Franck, F. \& Coetzee, J., 1999. Kikuyu (Pennisetum clandestinum) pasture for sheep. 2. Production and nutritional status of ewes with or without lupin (Lupinus albus) supplementation. N. Z. J. Agric. Res. 42, 467-474.

Brien, F.D., Konstantinov, K.V. \& Greeff, J.C., 2002. Comparison of linear and threshold models for predicting direct and maternal genetic effects on number of lambs weaned in Western Australian Merinos. Proc. $7^{\text {th }}$ Wrld Cong. Genet. Appl. Livest. Prod. 18-23 August, Montpellier, France. 32, pp. 307-310.

Bunge, R., Thomas, D.L., Nash, T.G. \& Fernando, R.L., 1993. Performance of hair breeds and prolific wool breeds of sheep in Southern Illinois: Effect of breed of service sire on lamb production of Suffolk and Targhee ewes. J. Anim. Sci. 71, 321-325.

Carson, A.F., McClinton, L.W. \& Steen, R.W.J., 1999. Effects of Texel or Rouge de 1'Quest genes in lowland ewes and rams on ewe prolificacy, lamb viability and weaned lamb output. Anim. Sci. 68, 69-78.

Cloete, S.W.P., 1992. Observations on litter size, parturition and maternal behaviour in relation to lamb mortality in fecund Dormer and SA Mutton Merino ewes. S. Afr. J. Anim. Sci. 22, 214-221.

Cloete, S.W.P., Coetzee, J., Schoeman, S.J., Morris, J. \& Ten Hoope, J.M., 1999a. Production parameters for Merino, Dohne Merino and South African Mutton Merino sheep. Proc. Assoc. Advmnt Anim. Breed. Genet. 13, 189-193.

Cloete, S.W.P. \& Durand, A., 2000. The crossing of commercial Merino ewes with South African (SA) Meat Merino rams for an increased lamb output. Aust. J. Exp. Agric. 40, 11-16.

Cloete, S.W.P, Olivier, J.J. \& du Toit, E., 1999b. Age effects on wool traits in Merino lines differing in clean fleece weight. Proc. S. Afr. Soc. Anim. Sci. 37, $24-25$. 
Cloete, S.W.P., Olivier, J.J., Snyman, M.A. \& du Toit, E., 1998a. Genetic parameters and trends in a selection experiment for increased clean fleece weight involving South African Merinos. Aust. J. Exp. Agric. 38, 427-432.

Cloete, S.W.P. \& Scholtz, A.J., 1998. Lamb survival in relation to lambing and neonatal behaviour in medium wool Merino lines divergently selected for multiple rearing ability. Aust. J. Exp. Agric. 38, 801-811.

Cloete, S.W.P., Scholtz, A.J. \& Aucamp, B.B., 1998b. Environmental effects, heritability estimates and genetic trends in a Western Cape Dohne Merino nucleus flock. S. Afr. J. Anim. Sci. 28, 185-195.

De Villers, T.T. \& Cloete, S.W.P., 1984. The Dormer sheep breed. Proc. $2^{\text {nd }}$ Wrld Cong. Sheep Beef Cattle Breed. 16 - 19 April 1984, Pretoria. South African Stud Book and Livestock Improvement Association, Bloemfontein (1984). pp. 695-698.

Duguma, G.J., Schoeman, S.J., Cloete, S.W.P. \& Jordaan, G.F., 2002. Genetic parameter estimates of early growth traits in the Tygerhoek Merino flock. S. Afr. J. Anim. Sci. 32, 66-75.

Erasmus, L.S., 1965. Slaglamproduksie met die Merino as moederooi. M.Sc. Agric. thesis, University of Stellenbosch, South Africa.

Erasmus, L.S., De Kock, J.A. \& Grobler, J.W., 1983. Slaglamproduksie in die Suid-Kaap. Els. J. 7, 13-32.

Fourie, A.J. \& Cloete, S.W.P., 1993. Reproductive performance of commercial Merino, Dohne Merino and SA Mutton Merino flocks in the Southern Cape. S. Afr. J. Anim. Sci. 23, 104-110.

Gilmour, A.R., Cullis, B.R., Welham, S.J. \& Thompson, R., 1999. ASREML - Reference manuel. NSW Agriculture Biometric Bulletin No. 3. NSW Agriculture, Orange Agricultural Institute, Forest Road, Orange 2800, NSW, Australia.

Greeff, J.C., 1990. The Merino and modern production systems. Proc. World. Merino Conf. Volume 1, 3.2,1-33. 2-4 May, 1990, Pretoria, South Africa. (Merino Studbreeders' Society of South Africa, P.O. Box 109, Graaff-Reinet 6280, South Africa.)

Holst, P.J., Fogarty, N.M., Hopkins, D.L. \& Stanley, D.F., 1997. Lamb survival of Texel and Poll Dorset crossbred lambs. Proc. Assoc. Advmnt Anim. Breed. Genet. 12, 313-316.

Jorhensen, J.N., 1994. Estimation of genetic parameters for litter size in sheep using a non-linear method. Acta Agric. Scand. A. Anim. Sci. 44, 8-11.

Kleeman, D.O., South, M.H.L., Dolling, C.H.S. \& Ponzoni, R.W., 1983. Survival, growth and wool production of South Australian strong-wool Merino and first-cross Merino lambs from birth to 16 months of age. Aust. J. Exp. Agric. Anim. Husb. 23, 271-279.

Kotzé, J.J.J., 1950. Fat-lamb production in the sour-grassveld area. Farm. S. Afr. November 1950, 357-369.

Kotzé, J.J.J., 1951. The development of a mutton-woolled sheep for the sour-grassveld area. Farm. S. Afr. April 1951, 110-113.

Mortimer, S.I. \& Atkins, K.D., 1997. Improvement of Merino reproductive performance through bloodline substitution and crossing. Proc. Assoc. Advmnt Anim. Breed. Genet. 12, 404-407.

Nawaz, M., Meyer, H.H. \& Thomas, D.R., 1992. Performance of Polypay, Coopworth and crossbred ewes: II. Survival and cumulative lamb and wool production over 4 years. J. Anim. Sci. 70, 70-77.

Neser, F.W.C., Erasmus, G.J. \& van Wyk, J.B., 2000. Genetic studies on the South African Mutton Merino: growth traits. S. Afr. J. Anim. Sci. 30, 172-177.

Olivier, J.J., 1999. The South African Merino performance testing scheme. Proc. Assoc. Advmnt Anim. Breed. Genet. 13, 119-124.

Purvis, I.W. \& Hillard, M., 1997. Biology and genetics of reproduction. In: The genetics of sheep. Eds Piper, L. \& Ruvinsky, A., CAB International, Wallingford, Oxon, United Kingdom. pp. 375-394.

Read, S., 1996. Consumer demands of wool beyond 2000. Demands of wool and wool growers beyond 2000. SARDI Research report series, No 11. pp. 5-13.

Roux, C.Z., 1992. Maximum herd efficiency in meat production. III. Feeder-breeder dimorphism. S. Afr. J. Anim. Sci. 22, 11-15.

Schoeman, S.J., 1990. Productivity of purebred Dohne Merino, SA Mutton Merino and Dorper sheep under an intensive accelerated lambing system. Proc. $4^{\text {th }}$ Wrld Cong. Genet. Appl. Livest. Prod., Edinburgh, UK. 15, pp. 373-376.

Scrivener, C.J. \& Vizard, A.L., 1997. The relationship between reproductive performance, time of lambing and the staple strength of wool from Merino ewes. Wool Tech. Sheep Breed. 45, 120-128.

Van Wyk, J.B., 1992. A genetic evaluation of the Elsenburg Dormer stud. Ph.D. dissertation, University of the Orange Free State, Bloemfontein, South Africa. 
Vosloo L.P., 1967. Faktore wat die produksie en reproduksie van die Elsenburg Duitse Merinokudde beïnvloed. D.Sc. dissertation, University of Stellenbosch, Stellenbosch, South Africa.

Wang, N., Vandepitte, W., Van Hofstraeten, W. \& Van Isterdael, J., 1989. Crossbreeding between Suffolk, Flemisch Milksheep and Texel. 2. Estimation of crossbreeding effects for productive and reproductive performances. Rev. de l'Agric. 42, 673-680. 